\title{
ANALISIS NILAI PENDIDIKAN KARAKTER PADA GAGURITAN TAMTAM
}

\author{
Oleh \\ Putu Subawa \\ (Staf Pengajar pada Fakultas Dharma Acarya STAHN Mpu Kuturan Singaraja)
}

\begin{abstract}
ABSTRAK
Pijakan utama yang harus dijadikan sebagai landasan dalam menerapkan pendidikan karakter adalah nilai moral universal yang dapat digali dari agama. Nilai melukiskan suatu harga yang diyakini seseorang (termasuk di dalamnya keyakinan normatif). Nilai adalah sesuatu yang abstrak yang harganya mensifati atau disifati pada sesuatu hal dan ciri-cirinya dapat dilihat dari tingkah laku, memiliki kaitan dengan istilah fakta, tindakan, norma moral, cita-cita, keyakinan, dan kebutuhan. Nilai dalam hal ini adalah ajaran-ajaran yang terdapat dalam Weda atau Kitab Suci Agama Hindu, khususnya terdapat dalam lontar, kekawin-kekawin, geguritan-geguritan yang ada di Bali, oleh karena itu nilai yang bersumber dari kitab suci ini adalah merupakan cara penanaman nilai yang terbaik pada diri pribadi pada setiap orang.
\end{abstract}

Kata Kunci : Pijakan utama yang harus dijadikan sebagai landasan

ABSTRACT

Major foothold which should serve as the basis to implement character education is a universal moral values that can be extracted from religion. Value depicts a man believed to be the price (including normative beliefs). Value is something abstract that cost mensifati or disifati on something and characteristics can be seen from the behavior, has nothing to do with the term fact, action, moral norms, ideals, beliefs, and needs. Values in this case are the teachings contained in the Holy Scriptures Vedas or Hinduism, especially there in the palm, kekawinkekawin, gaguritan-gaguritan in Bali, therefore the value that comes from this scripture is a way of planting the best value on personal self to everyone.

\section{Keywords : Major foothold which should serve as the basis}

\section{PENDAHULUAN}

UNESCO (United Nation for Educational, Scientific, and Cultural Organization ) menyatakan bahwa terdapat Empat Pilar Pendidikan, yakni (1) learning to know, (2) learning to do (3) learning to be (4) learning how to live together. Empat pilar pendidikan tersebut memberikan indikasi bahwa hasil pendidikan dewasa ini diarahkan untuk dapat menghasilkan manusia yang memiliki ciri-ciri manusia paripurna sesuai dengan tujuan pendidikan yang diharapkan. Pertama, learning to know. Dalam pilar ini, belajar dimaknai sebagai upaya hanya sebatas untuk mengetahui. Belajar ini termasuk dalam katagori sebagai belajar pada tingkat rendah, yakni belajar yang hanya menekankan pada ranah kognitif. Kedua, learning to do. Dalam pilar ini, belajar dimaknai sebagai upaya untuk membuat peserta didik bukan hanya mengetahui, tetapi lebih kepada dapat melakukan atau mengerjakan kegiatan tertentu. 
Fokus pembelajaran pada pilar ini adalah pada ranah psikomotorik. Ketiga, learning to be. Dalam pilar ketiga ini, belajar dimaknai sebagai upaya untuk menjadikan peserta didik sebagai dirinya sendiri. Belajar dalam konteks ini bertujuan untuk meningkatkan dan mengembangkan potensi peserta didik, sesuai dengan minat dan bakatnya atau tipetipe kecerdasannya (types of intellegence). Keempat, learning how to live together. Pilar ini memaknai belajar sebagai upaya agar peserta didik dapat hidup bersama dengan sesamanya secara damai. Dikaitkan dengan tipe-tipe kecerdasan, maka pilar keempat ini berupaya menjadikan peserta didik memiliki kecerdasan sosial (social inttelegence) ( Suparlan , 2008:38-39).

Pernyataan dari UNESCO itu menyadarkan bahwa proses belajar mengajar di dalam kelas bukan hanya diperlukan agar peserta didik dapat memperoleh pengetahuan sebanyak-banyaknya semata, tetapi harus lebih banyak memperoleh pengalaman, diberikan kesempatan agar pada akhirnya dapat melakukan atau mengerjakan sendiri. Dengan proses seperti itu, peserta didik dapat menjadi dirinya sendiri sesuai dengan potensi bakat dan minat yang mereka miliki. Di samping itu, yang tidak kalah penting adalah agar peserta didik mampu untuk dapat hidup bersama dalam masyarakat yang semakin mejemuk. Sesuai dengan Undang-Undang Republik Indonesia Nomor 20 Tahun 2003 tentang Sistem Pendidikan Nasional, pasal 3 yang dinyatakan: Pendidikan nasional berfungsi mengembangkan kemampuan dan membentuk watak serta peradaban bangsa yang bermartabat dalam rangka mencerdaskan kehidupan bangsa, bertujuan untuk berkembangnya potensi peserta didik agar menjadi manusia yang beriman dan bertakwa kepada Tuhan Yang Maha Esa,berakhlak mulia, sehat, berilmu, cakap, kreatif, mandiri, dan menjadi warga negara yang demokratis serta bertanggung jawab. (UU RI No. 20 : 8)
Dapat disimak dari uraian UndangUndang Republik Indonesia Nomor 20 Tahun 2003 pasal 3 adalah proses pendidikan bertujuan untuk mengembangkan potensi peserta didik sehingga menjadi berakhlak mulia, sehat, berilmu, cakap, kreatif, mandiri, dan ,menjadi warga negara yang demokratis serta bertaggung jawab.

Sejak tahun 2010, pemerintah melalui Menteri Pendidikan Nasional mencanangkan penerapan pendidikan karakter bagi semua tingkat pendidikan, baik sekolah dasar hingga perguruan tinggi. Program ini direncanakan bukan tanpa alasan. Sebab, selama ini, dunia pendidikan dinilai kurang berhasil dalam mengantarkan generasi bangsa menjadi pribadi-pribadi yang bermartabat.

Fenomena tersebut jelas menimbulkan kekhawatiran tersendiri bagi banyak kalangan. Negara ini memiliki banyak orang cerdas, namun ternyata mental dan prilaku mereka sama sekali tidak cerdas, bahkan, tidak terdapat korelasi antara tingginya nilai yang diperoleh di bangku pendidikan dengan prilaku mereka ditengah-tengah masyarakat. Akibatnya, muncullah sosok-sosok orang pandai yang memperalat orang bodoh atau orang pandai yang menindas orang lemah. Padahal, pada hakikatnya, pendidikan dilaksanakan bukan sekedar untuk mengejar nilai-nilai, melainkan memberikan pangarahan kepada setiap orang agar dapat bertindak dan bersikap benar sesuai dengan kaidah-kaidah dan sepirit keilmuan yang dipelajari. Tercapainya prinsip tersebut tentunya sangat berhubungan erat dengan tugas guru sebagai tenaga pendidik. Seorang guru harus benar-benar mampu memberikan penjelasan mengenai tujuan pendidikan dan cara bersikap yang semestinya. Sebab, mendidik adalah kegiatan member pengajaran kepada pesert didik, membuatnya mampu memahami sesuatu, dan dengan pemahaman yang dimilikinya, akan dapat mengembangkan potensi dirinya dengan menerapkan sesuatu yang telah dipelajarinya. Dari sekian banyak geguritan yang ada, yang menjadi fokus 
dalam tulisan ini adalah gaguritan Tamtam. Gaguritan Tamtam merupakan sebuah karya sastra yang pengarangnya bersifat anonym atau tanpa menyebut nama pengarang, hal ini mencerminkan sifat rendah hati yang dimiliki oleh sang pengarang. Gaguritan Tamtam banyak mengandung nilai-nilai baik berupa ajaran Agama Hindu ataupun nilainilai pendidikan secara umum. Banyaknya nilai-nilai yang terkandung dalam geguritan Tamtam ini menimbulkan daya tarik yang kuat untuk diteliti lebih dalam guna dapat dijadikan pegangan dalam kehidupan. Sebagai salah satu karya sastra yang banyak mengandung nilai spiritual dan nilai pendidikan yang universal maka geguritan Tamtam akan dapat dijadikan perbandingan khususnya dalam lingkup pendidikan baik pendidikan formal ataupun non-formal, apalagi dewasa ini pemerintah secara nasional melaksanakan model pendidikan yang berkarakter. Menurut Dewa Komang Tantra (dalam harian umum Nusa Bali, 18 Maret 2012 hal.1dan 15) menyatakan bahwa dalam keyakinan Hindu, anak yang berkarakter bersinonim dengan anak suputra. Ini berarti anak yang berkarakter identik dengan anak yang prilakunya sesuai dengan nilai-nilai yang terdapat dalam ajaran agama dan geguritan merupakan implementasi dari nilai-nilai tersebut.

\section{PEMBAHASAN \\ Gaguritan Tamtam}

Gaguritan Tamtam yang dijadikan sumber merupakan karya sastra yang telah mengalami penggubahan dalam bentuk buku yang diterbitkan oleh toko buku Indrajaya Singaraja. Hal ini duraikan mengingat terdapat berbagai versi yang peneliti temukan, ada yang merupakan hasil karya dari Amlapura dan ada juga yang hasil karya dari Tabanan. Oleh Toko Buku Indra Jaya, buku ini di susun kembali ke dalam dua jilid. Namun karena keterbatasan sarana buku Gegritan Tamtam ini hanya bisa di cetak jilid satu saja, sedangkan naskah keduanya hilang pada saat terjadi banjir pada tahun 1970. Sampai tahun 1998 geguritan tamtam ini sudah tersebar sebanyak 126000 eksemplar. Pada tahun 2006, atas Keinginan dari Nyoman Muliady Mintharsa, pemilik toko buku Indra Jaya dan Percetakan Mutiara untuk menggali kembali susastra Bali yang telah lama tenggelam agar berkembang kembali, kemudian beliau menyuruh I Ketut Marma .A.Ma Pd. untuk menyusun kembali Geguritan Tamtam ke dalam huruf latin, untuk di cetak dan di perbanyak.Untuk menjaga agar keutuhan teks naskah geguritan tamtam ini agar tidak terpisah pisah, maka naskag geguritan tamtam ini di jadikan kedalam satu jilid, sejak tahun 2006 geguritan tamtam yang lengkap di cetak dan di perbanyak untuk masyarakat umum, dan sampai tahun 2012 sekarang ini geguritan tamtam yang sudah tersebar sebanyak 165.000 eksemplar.

Gaguritan Tamtam merupakan salah satu karya sastra yang berbentuk tembang tradisional Bali, yang diikat oleh aturanaturan. Krangka dasar yang membangun cerita Geguritan Tamtam terdiri dari manggala, inti cerita (copus) dan penutup (epilog). Ketiga kerangka dasar itu yang merupakan struktur yang membangun cerita tersebut

\section{Bentuk Geguritan Tamtam}

Geguritan Tamtam merupakan salah satu karya sastra yang berbentuk tembang tradisional Bali, yang diikat oleh aturanaturan. Krangka dasar yang membangun cerita Geguritan Tamtam terdiri dari manggala, inti cerita (copus) dan penutup (epilog). Ketiga kerangka dasar itu yang merupakan struktur yang membangun cerita tersebut

\section{Manggala}

Manggala pada umumnya terdapat dalam karya sastra kakawin, biasanya ditulis pada bagian permulaan dari karya sastra tersebut. Demikian pula jenis karyasastra geguritan tidak terlepas dari manggala. Manggala adalah bait-bait pendahuluan sastra Hindu ( Jawa Kuna ). Pada bagian ini seringkali 
terdapat simpul-simpul inti teks (Suka Yasa, tt: 1). Pada umumnya merupakan bahasa puja pada ista dewata yang menjadi sesebahannya. Sering juga erimplisit tentang diri sang penyair dan saat kapan syair itu diubah. Disamping itu, manggala sering difungsikan penyair untuk memulai pengungkapan pesan-pesan, sebagai persepsi penikmat masuk dalam materi yang sebenarnya. Dalam kamus KawiBali kata manggala diartikan pangasungkara, pemambah, pengaksama, 'penghormatan, urain singkat, permohonan maaf. (Tim Penyusun, 1988:185).

Sebagai contoh manggala dapat dilihat pada salah satu karya kakawin, pilih saja kakawin Arjuna Wiwaha, pada bait pertama merupakan pujian kepada maha resi yang telah mencapai kesempurnaan, yang selaubertujuan untuk kebaikan dunia. Keberadaan beliau disamakan dengan Dewa Siwa. Pada bait kedua sang pengarang mengadakan penghormatan pada Maha Rsi yang telah sempurna, memohon anugrah dalam penulisan karya tersebut. Berikut petikannya "Usni sangkwi lebuni pauka nira sangmangkanaluwir nira, manggeh manggalaning miket kawijayan Sang Parta ring kahyangan, ...."'sembah bakti hamba kepada beliau yang telah sempurna, bagaikan anugrah pada hamba dalam menulis kemenangan Sang Arjuna di Sorga'. (1,2). Dalam bait manggala tersebut tidak saja berupa penghormatan, berfungsi juga sebagai pemambah tentang ide cerita selanjunya.

Manggala Gaguritan. Tamtam, dapat dilihat pada bait pertama sampai bait empat disajikan dengan pupuh sinom, berikut petikanya.

Pangkah tityang nganggit gita, Katah sane salah indek, Sok mewasta milu nuutang, Kawiwara katuutin, Sanget kardin idane luih, Kapinging wong lintang dusun, Prasadama tanding surya, katuran bekel dumadi, ring sang putus ,galang kadi nabastala (1)

Terjemahan :

Sangat berani saya mengarang nyanyian,
Tentu banyak salah aturan, Niat ingin meniru,mengikuti para pengarang yang agung, Karya-karya beliau sangat indah Dibandingkan dengan orang yang kampong yang bodoh ,Seperti kunang-kunang dibandingkan matahari ,Menceritakan bekal hidup ,Orang yang telah sempurna ,Bersih seperti bulan purnama .

Dahat sinampura pisan, Pupuh lagu tuna luih ,Plambang luir anak punyah.Wantah ipun uning carik, Saking pangkah milu ngawi ,Tuna satra mude punggung, Saking purun kaguyonan ,Prama sastra tan paindik, salah antuk, keramane papujolan (2)

Terjemahan :

mohon maaf yang sebesar-besarnya ,pupuh ini sangatlah tidak baik, berani seperti orang mabuk, hanya bisa berkata-kata,sangat berani turun mengarang, kurang pengetahuan muda dan bodoh, tidak takut jelek ,tidak tahu sasra utama, biasa kalah ,karena itu penyampaiannya sederhana

kewale bise ngucapang ,bisane angen akidik, adoh pacing mengrasayang ,kadi pitekete sami, kalingke ada sulinggih, pancasila adoh kantun, dumadak ring para loka ,ide dane manindakin, kardi putus ,nyungkemin kadi perlambang (3)

\section{Terjemahan}

hanya bias mengatakan, tahu hanya sedikit, jauhlah rasanya bias merasakan ,seperti apa yang dipesankan, jangankan ajaran pendeta ,tenang lima susilapu masih jauh, semogalah dalam masyarakat ,saudara bias menjalankan ,perbuatan baik, seperti contoh yang diajarkan

saking meled nyeritaang ,panumadi anak becik, wiwit saking pulo jawa, ginal-ginul maka nami, sisian ide peranda sakit, aji saka sane dumun, mengandakang anak melah wirya budi tan sinipi, silar-silur , manumadi dadi lanang (4) 
Terjemahan

sangat tertarik untuk meceritakan, kelahiran manusia utama, berasal dari pulau jawa, ginal-ginul namanya, sebagai murid pendeta utama ,bernama Ajisaka dizaman dahulu , beliau menjadi manusia utama, baik dan pintar tiada tanding ,bertukar kelamin saa menjelma kembali ke dunia

Bila diperhatikan petikan di atas merupakan pengaksama 'permakluman' sang pengarang dengan memilih kaa-kata, bergaya merendahkan diri. Pada bait berikunya juga merupakan pengaksama ; "permohon maaf", dan bai ke empat merupakan pemambah 'uraian tentang isi cerita selanjunya.

\section{Inti Cerita (Corpus)}

Punarbawa, adalah kepercayaan terhadap kelahiran yang berulang-ulang, tersirat dalam karya Geguritan Tamtam, merupakan pesan penting yang disampaikan sang kawi. Seperti di sebut dalam syair sakeng meled nyeritayang, panumadian anak becik. 'karena sangat ingin menceritakan, kelahiran anak baik'. Dilanjutkan dengan syair cutek mangkin nyeritayang, doning ceceh manumadi 'singkat cerita, karena kelahiran yang berulang-ulang'. Petikan syair di ats kiranya cukupkuat memberikan penafsiran, bahwa punarbawa adalah pesan penting yang hendak disampaikan oleh pengarang kepada pembaca atau penikmat.

Tentang sorga syuta ' kelahiran dari alam sorga' juga merupakan penekaan penting. Sesuai dengan tujuan kehidupan yang dirumuskan banyak orang adalah untuk mencapai kebahagian dan kedamaian hidup. Syarat untuk bisa lahi menjadi orang yang penuh kebahagian, kemasyuran adalah perbuatan yang baik (sesuai dengan normanorma, baik norma agama maupun norma masyarakat). Kemudian menjadi karma wesana 'hasil perbuatan terdahulu' yang menetukan keadaan kelahiran sekarang. Seperti kisah Ginal-Ginul telah berada di alam sorga, mereka berdua lahir kedunia menjadi orang yang mulia dan dihormatioleh masyarakat, berwajah tampan dan cantik, pintar dan wibuhing arta 'kaya raya'.

Pesan penting aygn juga dipesankan pengarang adalah tata cara perkawinan yang baik agar keturunannya menjadi baik. Salah satu diantaranya adalah perlu memperhatikan dengan jelas siap calon pasangan kita. Kalau dia laki-laki agar mencari istri yang sesuai dengan petunjuk sastra, agar jangan menyesal dikemudian hari. Karena tidak baik bergantiganti pasangan, maka dari tiu sebelum kawin perhatikanlah baik-baik petunjuk sastra tentang wanita yang pantas dijadikan istri, seperti ayng tersurat dalam abit berikut :

Tereh istrine utama, diastu ipun bangsa napi Ne rahayu akri anom, manelebang daging tutur, Saking kumpi, kaki bapa, miwah bibi Suluhne melaksana melah Tindak patut budi melah, wiweka nibankang munyi Nora tereh sakit abot, miwah snae sakti buduh Wiadinne makrida, parus munyi Nika suluh juwa tatasang

Terjemahan :

Keturunan istri utama, dari bangsa apapun ida berasal, Dia sehat dan masih muda, memahami ajaran agama, Dari kakek, kumpi, dan ayahnya, demikian juga ibunya Selalu berkaca dengan perbuatan baik Kelakuannya baik dan berbudi pekerti Selalu berfikir untuk berkata-kata, Tidak dari keutrunan sakit parah Dan juga tidak keturunan sakir gila Dan bukan pula keturunan maling maling Yang berkatakata tanpa berfikir Itulah pedoman yang harus diperhatikan.

Dan diuraikan pula seorang wanita yang patut dihindari untuk di jadikan istri. Disebut salah ambilan 'salah mengambil' seperti;anak nyuang tumin 'mengmabila saudara tiri', nyuang misan 'mengambil saudara misan', nyuang tugelan 'mengambil saudara kandung', balun nyama kelihan 'janda kaka', balun nyama cerikan 'janda adik' dan yang disebut rangda tiga 'janda tiga 
kali' itu juga tidak dibenarkan untuk dinikahi. Terkait dengan perkawinan pesan penting dari pengarang, bahwa tidak dibenarkan mengadakan hubungan sex sebelum menikah. Hubungan sex diperbolehkan, bila sudah melalui beberapa proses, seperti melakukan prosesi ritual mesakapan 'upacara pernikahan' yang didasari perasaan suka sama suka dan mendapat restu orang tua serta mendapatkan kesaksian dari masyarakat. Seperti tersebut dalam petikan pupuh sinom berikut ini:

Pewaragane adungan, wau kengin anggen rabi Upakarane puputang, sapolahe ngalap rabi, Ngawit patemune pasti, acumbuwana ring sang ayu, Samara gama pastika, pada gelarang sareng rabi, Saking adung, patemune jantos pragat.

Terjemahan

Sesama orang tua supaya setuju, barulah bisa diperistri Upacaranya diselesaikan, sebagaimana upacara perkawinan, Mengawali pertemuan yang pasti, bermesraan dengan si jelita Tutunan tatacara perkawinan harus dipahami, Dilaksanakan bersama istri, dengan niat yang menyatu Pertemuannya sampai selesai.

Demikianlah beberapa tema yang penting yang dapat diungkap dalam teks Gaguritan Tamtam, sungguh syarat dengan pesan-pesan yang hendaknya bisa dipakai panutan dalam kehidupan ini. Pendek kata naskah Gaguritan Tamtam penuh dengan pesan-pesan agama hindu dari segi tattwa, susila dan pentingnya umat manusia melakukan ritual agama.

\section{Penutup (Epilog)}

Bagian penutup, sebagai penutup karya satra ini, sang kawi bertutur tentang ajaran kebenaran itu sesungghnya sangat rahasia dan sangat luas, sehingga tidak bisa diungkap hanya dengan kata-kata dan sangat jarang yang mungkin tahu persis mengenai kebenaran itu secara tuntas. Seperti diungkapkan dalam petikan berikut:
Tan puput ojah baan munyi, Doning banget lintang singid, Arang waiakti anak tahu, Narane si sinunggal, Yan tan purun maurukin, Nalih suwung, Mangda sida nemu galang.

Terjemahan :

Tidak selesai hanya dibicarakan dengan kata-kata, Karena itu bersifat sangat rahasia, Sangatlah jarang orang yang tahu persis, Manusia seribu mungkin hanya satu orang, Bila tidak mau mempelajari, mencari kosong, Agar bisa menemukan terang.

Dalam bait penutup ini rupanya si pengarang mengharapkan kembali agar umat mau mempelajari dengan sungguh-sungguh ajaran-ajaran agama agama agar mendapat petunjuk sebagai pedoman dalam menjalani kehidupan ini. Bila tidak mau mempelajarinya tentu kehidupan ini akan gelap gulita.

\section{Tema Gaguritan Tamtam}

Untuk melengkapi konsep tentang tema, Sapardi Djoko Damono mengatakan bahwa, pengarang mempunyai niat untuk menyamoaikan nilai-nilai hidup yang berguna bagi pembaca, seperti kesetiaan, cinta, dan masalah-masalah social lainnya, lalu diabstraksikan kedalam karyanya. Hal yang disampaikan itu dinyatakan sebagai tema sebuah cipta sastra (Edi Setyawati, 1983 : 8). Tema dari karya sastra Gaguritan Tamtam adalah tentang kelahira anak manusia yang tekun mempelajari ajaran agama sehingga memperoleh kemasyuran dalam kehidupannya.

Punarbawa, adalah kepercayaan terhadap kelahiran yang berulang-ulang, tersirat dalam karya Geguritan Tamtam, merupakan pesan penting yang disampaikan sang kawi. Seperti di sebut dalam syair sakeng meled nyeritayang, panumadian anak becik. 
'karena sangat ingin menceritakan, kelahiran anak baik'. Dilanjutkan dengan syair cutek mangkin nyeritayang, doning ceceh manumadi 'singkat cerita, karena kelahiran yang berulang-ulang'. Petikan syair di ats kiranya cukupkuat memberikan penafsiran, bahwa punarbawa adalah pesan penting yang hendak disampaikan oleh pengarang kepada pembaca atau penikmat.

Tentang sorga syuta ' kelahiran dari alam sorga' juga merupakan penekaan penting. Sesuai dengan tujuan kehidupan yang dirumuskan banyak orang adalah untuk mencapai kebahagian dan kedamaian hidup. Syarat untuk bisa lahi menjadi orang yang penuh kebahagian, kemasyuran adalah perbuatan yang baik (sesuai dengan normanorma, baik norma agama maupun norma masyarakat). Kemudian menjadi karma wesana 'hasil perbuatan terdahulu' yang menetukan keadaan kelahiran sekarang. Seperti kisah Ginal-Ginul telah berada di alam sorga, mereka berdua lahir kedunia menjadi orang yang mulia dan dihormatioleh masyarakat, berwajah tampan dan cantik, pintar dan wibuhing arta 'kaya raya'. Pesan penting yang juga dipesankan pengarang adalah tata cara sperkawinan yang baik agar keturunannya menjadi baik. Salah satu diantaranya adalah perlu memperhatikan dengan jelas siap calon pasangan kita. Kalau dia laki-laki agar mencari istri yang sesuai dengan petunjuk sastra, agar jangan menyesal dikemudian hari. Karena tidak baik bergantiganti pasangan, maka dari tiu sebelum kawin perhatikanlah baik-baik petunjuk sastra tentang wanita yang pantas dijadikan istri.

\section{Bahasa}

Bahasa memegang peran penting dalam sebuah karya sastra, menurut Jendra (2001:11) dalam makalahnya yang berjudul Pendidikan Nilai-Nilai Kemanusiaan Sebagai Basis Budi Pekerti Sebuah Analisis Religiososiollinguistik mengemukakan bahasa berperan sebagai media religious spiritual.
Bahasa juga merupakan system lambing bunyi yang dipakai oleh suatu masyarakat untuk berinteraksi. Percakapan yang baik, tingkah laku yang baik, sopan santun, bahasa menunjukkan bangsa merupakan cirri seseorang menunjukkan dari mana dia berasal. Budi bahasa seseorang mencerminkan tingkat keluhuran keturunannya (lingkungan keluarganya). Geguritan Tamtam yang dikaji dalam tulisan ini menggunakan Bahasa Bali campuran, (terdiri dari bahasa sansekerta, bahasa kawi, dan bahasa Bali). Hal ini dimaksudkan supaya lebih mudah memperoleh pemahaman juga lebih mempermudah dalam menghayatinya. Dengan hal tersebut nilainilai yang terkandung didalamnya akan mudah ditransformasikan dalam kehidupan bermasyarakat.

\section{Analisis Nilai Pendidikan Karakter pada Gaguritan Tamtam}

Analisis nilai pendidikan karakter yang terkandung dalam Geguritan Tamtam, dalam penelitian ini pembedahannya menggunakan teorinya F.W Foerster. Menurut Foerster ada empat ciri dasar dalam pendidikan karakter. Pertama, keteraturan interior di mana setiap tindakan diukur berdasar hierarki nilai. Nilai menjadi pedoman normatif setiap tindakan. Kedua, koherensi yang memberi keberanian, membuat seseorang teguh pada prinsip,tidak mudah terombang-ambing pada situasi baru atau takut risiko. Koherensi merupakan dasar yang membangun rasa percaya satu sama lain. Tidak adanya koherensi meruntuhkan kredibilitas seseorang. Ketiga, otonomi. Di situ seseorang menginternalisasikan aturan dari luar sampai menjadi nilaai-nilai bagi pribadi. Ini dapat dilihat lewat penilaian atas keputusan pribadi tanpa terpengaruh atau desakan pihak lain.Keempat, keteguhan dan kesetiaan. Keteguhan merupakan daya tahan seseorang guna mengingini apa yang dipandang baik. Dan kesetiaan merupakan dasar bagi penghormatan atas komitmen yang dipilih. 
Tabel. 2.1

\section{ANALISIS PENDIDIKAN KARAKTER DALAM GEGURITAN TAMTAM}

\begin{tabular}{|c|c|c|c|c|c|}
\hline \multirow{2}{*}{ Pupuh } & \multirow{2}{*}{$\begin{array}{l}\text { Jumlah } \\
\text { Pupuh }\end{array}$} & \multicolumn{4}{|c|}{ Nilai Pendidikan Karakter } \\
\hline & & Keteraturan & Koherensi & Otonomi & $\begin{array}{l}\text { Keteguhan dan } \\
\text { Kesetiaan }\end{array}$ \\
\hline Sinom & 191 & $\begin{array}{l}2,3,13,14,15,18,44, \\
4546,56,59,62,132, \\
137\end{array}$ & 17,90 & 27,77 & $89,99,127,142,149$, \\
\hline Semarandana & 72 & $29,34,35,50$ & 28,51 & & \\
\hline Ginada & 88 & $56,58,59,60,72$ & 2 & $3,31,32$ & \\
\hline Pangkur & 18 & $15,16,18$ & & & \\
\hline Ginanti & 83 & 71,72 & 33 & 15,16 & \\
\hline Durma & 20 & $4,6,18$ & 7,12 & & 9 \\
\hline Adri & 14 & $4,5,11,12$ & 7,8 & & \\
\hline Pucung & 32 & & 12,29 & & \\
\hline Kumambang & 17 & 13,15 & 12 & & \\
\hline Mijil & 10 & $2,3,6$ & 4,8 & & \\
\hline Dandang & 15 & 12 & & & 5 \\
\hline Megatruh & 45 & $5,10,11$ & & & 13 \\
\hline Jml & 605 & & & & \\
\hline
\end{tabular}

\section{PENUTUP}

Bertolak dari uraian-uraian diatas, maka dapat disimpulkan hal-hal sebagai berikut :

a. Nilai Keteraturan Interior dalam Geguritan Relevansinya dengan Sistem Pendidikan Nasional dipandang sangat relevan karena geguritan Tamtam Pada gaguritan tamtam banyak terdapat tata susunan nilai yang dapat dijadikan acuan didalam mewujudkan tujuan pendidikan yang diharapkan. Karakter dapat dianggap sebagai nilai-nilai perilakumanusia yang berhubungan dengan Tuhan Yang Maha Esa, diri sendiri, sesama manusia.

b. Nilai Koherensi dari geguritan Tamtam dan Relevansinya dengan Sistem Pendidikan
Nasional dimana Peserta didik tidak akan memiliki jiwa kemandirian (koherensi) dan hanya sekedar tau tanpa pernah mengerti apa yangdii berikan. Kenyataan ini nampaknya justru disambut dengan antusias oleh banyak lembaga pendidikan.

c. Nilai Otonomi dari geguritan Tamtam dan Relevansinya terhadap Sistem Pendidikan Nasional adalah pendidikan sebenarnya mengarahkan manusia menjadi insan yang sadar diri dan sadar lingkungan. Dari kesadarannya itu mampu memperbarui diri dan lingkungannya tanpa kehilangan kepribadian dan tidak tercerabut dari akar tradisinya. Kepribadian yang dihasilkan seperti ini merupakan nilai yang bersifat 
otonom, karena manusia akan memiliki prinsip yang kuat tanpa mudah terpengaruh oleh pemahaman yang menurutnya dianggap tidak tepat.

d. Nilai Keteguhan dan Kesetiaan dari geguritan Tamtam dengan Sistem Pendidikan Nasional adalah dalam perkataan, tindakan, dan pekerjaan, juga disiplin dalam tindakan yang menunjukkan perilaku tertib dan patuh pada berbagai ketentuan dan peraturan serta menunjukkan upaya sungguhsungguh dalam mengatasi berbagai hambatan, karena keteguhan merupakan daya tahan seseorang untuk mengingini apa yang dipandang baik, sedangan kesetiaan merupakan dasar bagi penghormatan atas komitmen yang dipilih.

\section{DAFTAR PUSTAKA}

Agastya. I B.G, 1987 Wrtasancaya Gitasancaya kumpulan wirama dan pupuh, denpasar , wyasa sanggraha.

Dimyati dan Mudjiono, 2006. Belajar dan Pembelajaran. Jakarta : Rineka Cipta.

Imron, Ali, 2008. Kebijakan Pendidikan Di Indonesia. Jakarta: Bumi Aksara

Mu in, Fatchun, 2011. Pendidikan Karakter. Jogjakarta: AR-Ruzz Media

Pidarta, Made, 2000. Landasan Pendidikan : Stimulus Ilmu Pendidikan Bercorak

Indonesia. Jakarta : Rineka Cipta.

Rani, Abdul. 2006. Analisis Wacana: Sebuah Kajian Bahasa dalam Pemakaian. Malang: Bayumedia Publishing.

Simpen , Iwayan AB, 1983, Kamus bahasa bali , Pt Maha Bhakti-Denpasar
Suarka I Nyoman,2007. Kidung Tantri Pisacarana:Suntingan Teks, Terjemahan dan

Pendekatan Semiotik,Desertasi, Yogyak arta:UGM

Tim Penyusun, 1991. Kamus Besar Bahasa Indonesia. Jakarta: Balai Pustaka.

Undang-Undang R.I Nomor 20 Tahun 2003 tentang Sistem Pendidikan Nasional. Jakarta: Departemen Pendidikan Nasional. 